\title{
Evaluation of WHO criteria to determine degree of dehydration in children with acute diarrhea
}

\author{
Suprawita Sari, MD; Supriatmo, MD; SL Margaretha, MD; S Nafianti, MD; \\ B Hasibuan, MD; AB Sinuhaji MD
}

\begin{abstract}
Objective To evaluate the diagnostic accuracy and agreement between the 1980 and 1990 WHO criteria for determining the degree of dehydration in children with acute diarrhea.

Methods This prospective study was conducted in two hospitals from October 2002 to February 2003. Clinical signs of dehydration all patients were recorded. The degree of dehydration based on the 1980 and 1990 WHO criteria was determined and compared with fluid deficit measured by the difference of body weight on admission and on discharge. Chi-square test and kappa value analyses were performed. Sensitivity, specificity, predictive values, and accuracy of each WHO criteria were assessed. The prevalence of dehydration was also determined.

Results Sixty-five patients, comprising 40 boys and 25 girls, were studied. There was a significant difference between the two WHO criteria in differentiating between dehydration and non-dehydration $(P<0.05)$. Based on the 1980 WHO criteria the prevalence of dehydration was $62.2 \%$. Its sensitivity, specificity, and accuracy in diagnosing dehydration were $100.0 \%, 55.5 \%$, and $86.2 \%$, respectively. Based on the 1990 WHO criteria, the prevalence of dehydration was $60.0 \%$. Its sensitivity, specificity, and accuracy in diagnosing dehydration were $94.9 \%, 46.1 \%$, and $75.4 \%$, respectively. There was also a significant difference between both criteria in determining severe dehydration $(\mathrm{P}<0.05)$. Based on the 1980 criteria, the prevalence of severe dehydration was $15.4 \%$. Its sensitivity, specificity, and accuracy in diagnosing severe dehydration were $30.0 \%, 94.5 \%$, and $84.6 \%$, respectively. Based on the 1990 criteria, these results were $40.0 \%, 94.5 \%$, and $86.2 \%$, respectively. The prevalence was $15.4 \%$. Kappa value comparing the two WHO criteria was 0.852 in diagnosing dehydration and 0.915 in diagnosing severe dehydration. There was no significant difference between the two criteria in their sensitivity and specificity $(P>0.05)$. Conclusion Both WHO criteria can be applied to determine dehydration in patients with acute diarrhea, although we feel that the 1990 criteria is simpler [Paediatr Indones 2005;45:76-80].
\end{abstract}

Keywords: WHO criteria, acute diarrhea, dehydration, fluid deficit, sensitivity, specificity, agreement

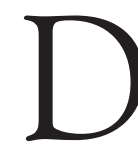
iarrhea is one of the leading causes of morbidity and mortality in children worldwide, causing one billion episodes of illness and $3-5$ million deaths annually. ${ }^{1,2}$ Diarrhea patients may die of dehydration; therefore, the main priority in treating diarrhea is early replacement of fluid and electrolyte to prevent and treat dehydration, as well as to prevent already rehydrated patients from dehydrating again.3,4,5 The amount of fluid required to replace fluid loss can be measured by the change of body weight during diarrhea, especially in children. If the true pre-illness weight is not known, an estimate of fluid deficit is made on clinical assessment. ${ }^{4-7}$

Maurice King (1974) recommended six clinical signs to determine dehydration i.e., general appearance, skin elasticity, eyes, anterior fontanelle, mouth, and radial pulse. ${ }^{8}$ In 1980 WHO recommended 10 clinical signs to determine dehydration based on general appearance and condition, radial pulse, respiration, anterior fontanelle, systolic blood pressure, skin elasticity, eyes, tears, mucous membranes, and urine

From the Department of Child Health, Medical School, University of North Sumatra, Medan/ Adam Malik Hospital, Medan, Indonesia.

Reprint requests to: Dr. Suprawita Sari, MD, Department of Child Health, University of North Sumatra, Adam Malik Hospital, Jl. Bunga Lau No.17 Medan 20136, Indonesia. Tel/Fax. 62-61-8361721. 
production. ${ }^{9}$ Both the 1980 WHO criteria and Maurice King's criteria classify dehydration as mild, moderate, or severe. ${ }^{8}$ Siregar reported that there was no significant difference between these two criteria in determining the degree of dehydration, except in children less than two years of age and malnourished children. ${ }^{10}$ Gorelick ${ }^{7}$ found that all 10 clinical signs (general appearance, quality of radial pulse, quality of respiration, skin elasticity, eyes, tears, mucous membranes, urine output, heart rate and capillary refill) in children with diarrhea were significantly associated with the presence of dehydration. The sensitivity of individual findings varied from 0.35 to 0.85 , and the specificity ranged from 0.53 to 0.97 . Gorelick recommended that the existing criteria for the diagnosis of dehydration in children be modified to reflect the fact that objective signs of dehydration are apparent with a fluid deficit of $<5 \%$. Of the 10 findings studied, none is sufficiently accurate to be used in isolation. The presence of fewer than three signs corresponds with a deficit of $<5 \%$, whereas children with deficit of $5 \%$ to $9 \%$ generally have three or more clinical findings. At least six to seven findings should be present to diagnose a deficit of $10 \%$ or more.

On the last revision (1990), WHO assessed six clinical signs to determine the degree of dehydration. ${ }^{11}$ Despite the enormous advances in recent decades in the treatment of dehydration, especially in the use of oral rehydration therapy, little attention has been focused on the clinical diagnosis of this condition. ${ }^{7}$ To our knowledge no study has been conducted on the accuracy of WHO criteria in determining dehydration in children with acute diarrhea.

\section{Methods}

This prospective study was conducted in the Gastroenterology Departments of H. Adam Malik and Pirngadi Hospitals, Medan from October 2003 to February 2003. Eligible subjects were all infants/ children with acute diarrhea treated in these departments as in- or outpatients. This study was approved by the $\mathrm{H}$. Adam Malik and Pirngadi Medan Hospital Medical Ethics Committee. Patients included were those with less than five days of acute diarrhea without any severe underlying disease such as severe pneumonia, encephalitis, or meningitis, who had received no medication for 12 hours prior to the diagnosis, and were wellnourished or mildly malnourished based on the National Center for Health Statistics (NCHS) standards. They were excluded if they received incomplete monitoring. All patients were recorded for age, weight, height, body temperature, and signs of dehydration based on the 1980 and 1990 WHO criteria. Assessment was done before rehydration. Fluid therapy was given based on the degree of dehydration according to the 1990 WHO criteria. Dehydration was defined as a fluid deficit of $5 \%$ or greater. Before medication, each patient's weight without slippers or shoes was measured using a MicHealth scale which had been calibrated with an accuracy of $0.1 \mathrm{~kg}$. Infants less than one year of age were weighed unclothed using a Tanita scale which had been calibrated with an accuracy of $0.05 \mathrm{~kg}$. Patients were weighed twice daily until discharge at $7 \mathrm{AM}$ and $7 \mathrm{PM}$ by an investigator or senior resident. For outpatients, home visits were done twice daily until the patient recovered. A patient's weight was considered stable if the two consecutive measurements differed by $<2 \%$; the mean of these weights was the final weight. The gold standard was fluid deficit measured by difference between body weight on admission and discharge. A patient was discharged if symptoms such as vomiting, diarrhea, fever, or abdominal pain had resolved. The person calculating the percentage of fluid deficit was kept blind to the patient's dehydration level at initial assessment.

Due to differences in the dehydration classification between the two WHO criteria, we evaluated the ability of each criterion to distinguish between dehydration and non-dehydration and between severe dehydration and non-severe dehydration. Data was analyzed with the chi-square test to seek the difference between proportions. A P value of $<0.05$ was considered significant. Agreement between both criteria was assessed by calculating the kappa value. Data was processed using SPSS for Windows version 10.0. The sensitivity, specificity, positive predictive value, negative predictive value, and accuracy of each criterion was calculated. The prevalence of dehydration and severe dehydration based on each criterion was also determined. Finally, sensitivity and specificity were compared between both WHO criteria. 


\section{Results}

Out of 65 patients studied, there were 40 boys and 25 girls. There was significant difference between the two criteria in distinguishing dehydration from nondehydration $(\mathrm{P}<0.05)$. The sensitivity, specificity, positive predictive value, negative predictive value, and accuracy of the $1980 \mathrm{WHO}$ criteria in diagnosing dehydration were $100.0 \%, 55.5 \%, 83.3 \%, 100.0 \%$, and $86.2 \%$, respectively. The prevalence of dehydration based on this criteria was $69.2 \%$. Meanwhile, the sensitivity, specificity, positive predictive value, negative predictive value, and accuracy of the 1990 WHO criteria were $94.9 \%, 46.1 \%, 72.5 \%, 85.7 \%$, and $75.4 \%$, respectively. The prevalence of dehydration was $60.0 \%$. There was also significant difference between the two criteria in distinguishing severe from non-severe dehydration $(\mathrm{P}<0.05)$. The sensitivity, specificity, positive predictive value, negative predictive value, and accuracy of the 1980 criteria in diagnosing severe dehydration were $30.0 \%, 94.5 \%$, $50.0 \%, 88.1 \%$, and $84.6 \%$, respectively, with a prevalence of $15.4 \%$. On the other hand, using the 1990 criteria, these results were $40.0 \%, 94.5 \%$, $57.1 \%, 89.6 \%$, and $86.2 \%$; respectively, with a prevalence of $15.4 \%$. Kappa value between the two criteria in diagnosing dehydration and severe dehydration measured by were 0.852 and 0.915 , respectively. In determining dehydration and severe dehydration, sensitivity and specificity values between the two criteria were not significantly different $(\mathrm{P}>0.05)$.

\section{Discussion}

In diagnosing dehydration, we found that sensitivity was high for both the 1980 and 1990 WHO criteria (100\% and $94.9 \%$, respectively). Both criteria showed significant difference between the proportion of patients with dehydration and that of those without dehydration $(\mathrm{P}<0.05)$. We also obtained high accuracy for both criteria $(86.2 \%$ and $75.4 \%$, respectively) in determining dehydration.

Kappa between the two WHO criteria was 0.852 for diagnosing dehydration and 0.915 for diagnosing severe dehydration. Kappa values of $>0.8$ are generally considered as indicating good agreement. ${ }^{12}$
Gorelick $^{7}$ found that sensitivity and specificity in determining dehydration of clinical findings ranged from 0.35 to 0.85 and 0.53 to 0.97 ; respectively. In contrast to our study, Gorelick's assessed each clinical finding separately. Of the 10 findings studied, none was sufficiently accurate to be used in isolation. To determine the presence of dehydration, three signs or more are required. In the study of Mackenzie et al ${ }^{13}$ clinical assessment was compared to actual weight change. Mackenzie's study showed that house officers commonly overestimated the degree of dehydration in children hospitalized for gastroenteritis. Of the 13 specific findings studied, decreased skin turgor, decreased peripheral perfusion, and deep (acidotic) breathing were found to be the best clinical indicators of dehydration. Serum urea of $>6.5 \mathrm{mmol} / \mathrm{l}$ and $\mathrm{pH}<7.35$ were positive signs associated with dehy-

Table 1. Assessment With diagnostic test and gold STANDARD BASED ON DEHYDRATION AND NO DEHYDRATION ACCORDING WHO CRITERIA 1980

\begin{tabular}{|c|c|c|c|}
\hline \multicolumn{4}{|c|}{ Gold standard (\% fluid deficit) } \\
\hline WHO criteria 1880 & dehydration & no dehydration & $\mathbf{N}$ \\
\hline dehydration & 45 & 9 & 54 \\
\hline no dehydration & 0 & 11 & 11 \\
\hline $\mathrm{N}$ & 45 & 20 & 65 \\
\hline
\end{tabular}

Table 2. Assessment With diagnostic test and Gold STANDARD BASED ON DEHYDRATION AND NO DEHYDRATION ACCORDING WHO CRITERIA 1990

\begin{tabular}{lccc}
\hline \multicolumn{4}{l}{ Gold standard (\% fluid deficit) } \\
\hline WHO criteria 1990 & dehydration & no dehydration & N \\
\hline dehydration & 37 & 14 & 51 \\
no dehydration & 2 & 12 & 14 \\
\hline \multicolumn{1}{c}{ N } & 39 & 26 & 65 \\
\hline$x^{2}=15.537 ;$ df $=1 ; \mathrm{P}=0.000$ & &
\end{tabular}

Table 3. Agreement between criteria of WHO 1980 AND WHO 1990 TO DETERMINE DEHYDRATION AND NO DEHYDRATION

\begin{tabular}{lccc}
\hline & \multicolumn{3}{l}{ WHO criteria 1990 } \\
\cline { 2 - 4 } WHO criteria 1980 & dehydration & no dehydration & $\mathbf{N}$ \\
\hline dehydration & 51 & 3 & 54 \\
no dehydration & 0 & 11 & 11 \\
\hline \multicolumn{1}{c}{ N } & 51 & 14 & 65 \\
\hline
\end{tabular}

ppa $=0.852$ 
Suprawita Sari et al: Evaluation of WHO criteria for dehydration in acute diarrhea

Table 4. Assessment With diagnostic test and Gold STANDARD BASED ON SEVERE DEHYDRATION AND NON SEVERE DEHYDRATION ACCORDING WHO CRITERIA 1980

\begin{tabular}{lccc}
\hline Gold standard (\% fluid deficit) & & \\
\hline WHO criteria 1990 & dehydration & no dehydration & $\mathbf{N}$ \\
\hline severe dehydration & 3 & 3 & 6 \\
non severe dehydration & 7 & 52 & 59 \\
\hline \multicolumn{1}{c}{$\mathrm{N}$} & 10 & 55 & 65 \\
\hline$x^{2}=6.084 ; \mathrm{df}=1 ; \mathrm{P}=0.014$ &
\end{tabular}

Table 5. Assessment With diagnostic test and gold STANDARD BASED ON SEVERE DEHYDRATION AND NON SEVERE DEHYDRATION ACCORDING WHO CRITERIA 1990

\begin{tabular}{lccc}
\hline Gold standard (\% fluid deficit) & & \\
\hline WHO criteria 1990 & dehydration & no dehydration & N \\
\hline severe dehydration & 4 & 3 & 7 \\
non severe dehydration & 6 & 52 & 58 \\
\hline \multicolumn{1}{c}{ N } & 10 & 55 & 65 \\
\hline$x^{2}=10.508 ; d f=1 ; P=0.014$ &
\end{tabular}

dration. However, the sensitivity and specificity of these signs were low.

In a prospective cohort study of children between 3 and 18 months of age in Egypt, Duggan and colleagues ${ }^{15}$ found that prolonged skinfold, dry oral mucosa, sunken eyes, and altered neurological status were the best clinical signs correlated with dehydration as determined by post-rehydration weight gain. Children with clinical signs of mild and moderate dehydration had fluid deficits of 3\% and 5\% body weight, respectively. ${ }^{15}$

In the studies of Duggan ${ }^{15}$ and Mackenzie, ${ }^{13}$ mild to moderate dehydration on clinical assessment was found to be represented by 3 to $5 \%$ of weight loss. Those with severe signs (circulatory collapse) had weight loss of $9-10 \%$. These studies agreed with the WHO guidelines on dehydration assessment.

The severity of dehydration is most accurately assessed in terms of weight. This was the gold standard against which other tests are measured..$^{14}$ In this study, we did not analyze the amount of fluid intake (oral, intravenous, intake from food) and fluid loss (vomiting, urine, feces).

We did not include patients with severe malnutrition because it is difficult to estimate dehydration status accurately in severely malnourished children using clinical signs alone. ${ }^{17}$ Since the
WHO criteria does not consider nutritional status in determining the degree of dehydration, further studies need to be done to determine whether these criteria can be used for patients with severe malnutrition.

In conclusion, both the 1980 and the $1990 \mathrm{WHO}$ criteria can be used to determine the degree of dehydration in patients with acute diarrhea. The investigators feel that the 1990 criteria is simpler.

\section{References}

1. Pickering LK, Snyder JD. Gastroenteritis. In: Behrman RE, Kliegman RM, Jenson HB, editors. Nelson textbook of pediatrics. $16^{\text {th }}$ ed. Philadelphia: Saunders; 2000. p. 765-8.

2. Firmansyah A. Cairan rehidrasi oral: manfaat dan pengembangannya. In: Trihono PP, Purnamawati S. Syarif DR, et al, editors. Hot topics in pediatrics II. Proceedings of Pendidikan Kedokteran Berkelanjutan Ilmu Kesehatan Anak XLV. Jakarta: FKUI; 2002. p. 141-5.

3. Adelman RD, Solhung MJ. Pathophysiology of body fluids and fluid therapy. In: Behrman RE, Kliegman RM, Jenson HB, editros. Nelson textbook of pediatrics. $16^{\text {th }}$ ed. Philadelphia: Saunders; 2000. p. 211-23.

4. Sinuhaji AB. Patofisiologi dan tatalaksana diare akut pada neonatus dan bayi. In: Pasaribu S, Lubis M, Lubis B, Akbar K, Saputra AM, editors. Penatalaksanaan diare pada bayi dan neonatus. Proceedings of Pendidikan Kedokteran Berkelanjutan, Ilmu Kesehatan Anak FK USU; 1999 Nov 22; Medan, Indonesia.

5. Sinuhaji AB. Prinsip umum pengobatan cairan parenteral pada bayi dan anak. Presented at Simposium Penatalaksanan Terapi Cairan pada Anak IDAI SU/ BIKA; 2000 Apr 22; Medan, Indonesia.

6. American Academy of Pediatrics Provisional Committee on Quality Improvement, Subcommittee on Acute Gastroenteritis. Practice parameter: the management of acute gastroenteritis in young children. Pediatrics 1996;97:424-33.

7. Gorelick MH, Shaw KN, Murphy KO. Validity and reliability of clinical signs in the diagnosis of dehydration in children. Pediatrics 1997;99:e6.

8. Suharyono, Boediarso A, Halimun EM, editors. Gastroenterologi Anak Praktis. Jakarta : FKUI; 1988. p. $59-60$. 


\section{Paediatrica Indonesiana}

9. World Health Organization. A manual for the treatment of acute diarrhoea. Geneva, Switzerland: Pogramme for control of diarrhoeal diseases. WHO/ CDD/SER/80.2.

10. Siregar AA, Lubis A, Sutanto AH, et al. Perbandingan scoring system WHO (1980) dan Maurice King (1974) pada anak dengan gastroenteritis dan dehidrasi di bagian Ilmu Kesehatan Anak FK - USU / RS. Dr. Pirngadi Medan. Medika 1987;1:80-6.

11. World Health Organization. A manual for the treatment of diarrhoea. For use by physicians and other senior health workers. Geneva, Switzerland: Programme for the control of diarrhoeal diseases. WHO/CDD/SER/ 80.2.Rev.2.1990.

12. Tumbelaka AR, Abdoerrachman MH, Latief A, Abdulsalam M, Darwis D. Pengukuran dalam penelitian. In: Sastroasmoro S, Ismael S, editors. Dasar- dasar metodologi penelitian klinis. 2nd edition. Jakarta: Sagung Seto; 2002. p. 49-66

13. Mackenzie A, Shan F, Barnes G. Clinical signs of dehydration in children. Lancet 1989;ii:1529-30.

14. Armon K, Stephenson T, MacFaul R, Eccleston P, Werneke U. An evidence and consensus based guideline for acute diarrhoea management. Arch Dis Child 2001;85:132-42.

15. Duggan C, Refat M, Hashem M, Wolff M, Fayad I, Santosham M. How valid are clinical signs of dehydration in infants? J Pediatr Gastroenterol Nutr 1996;22:56-61.

16. World Health Organization. Management of the child with a serious infection or severe malnutrition. Guidelines for care at the first-referral level in developing countries. Geneva, Switzerland: Department of child and adolescent health and development WHO; 2000. 